\title{
Teaching trauma management in the accident and emergency department
}

\author{
L. WILliAMS*, C. L. MUWANGA*, P. H. \\ WORLOCK ${ }^{\dagger}$, C. G. MORAN ${ }^{\dagger} \&$ K. A. PRICE
}

${ }^{*}$ Departments of Accident and Emergency, ${ }^{+}$Orthopaedics and ${ }^{\ddagger}$ Anaesthesia, District General Hospital, Kayll Road, Sunderland, SR4 7TP

\section{SUMMARY}

Since their introduction into the United Kingdom, Advanced Trauma Life Support Courses (ATLS) have preferentially offered places to Consultants and Senior Registrars. It is usual, however, for the initial resuscitation of the seriously injured patient to be performed by relatively inexperienced junior staff. It is incumbent upon those medical staff who are ATLS providers or instructors to design local courses, based upon ATLS principals, to train their junior staff in a structured approach to managing these patients. We describe one such local course which may serve as a model for others.

\section{INTRODUCTION}

Advanced Trauma Life Support (ATLS) Courses were introduced into the U.K. in November 1988. The courses are coordinated by the Royal College of Surgeons of England in association with the American College of Surgeons and teach medical staff an algorithmic, structured approach to the management of the seriously injured patient (ATLS Programme Instructor Manual, 1988).

The ATLS Programme has developed rapidly in the U.K.: One ATLS Provider Course was held in 1988, seven in 1989, 29 in 1990; it is anticipated that over 40 will be held during 1991. Although this expansion of the programme is welcome, the demand for places far outstrips the supply. The Royal College of Surgeons has preferentially allocated places on Provider Courses to Consultants and Senior Registrars anticipating that they will influence systems of care on return to their units. However, the seriously injured patient is likely to be met, in the resuscitation room, by relatively inexperienced junior medical staff. What can be done to train these doctors?

Correspondence: Miss L. Williams Accident \& Emergency Dept, District General Hospital, Sunderland SR4 7TP, U.K. 
The number of post-registration medical staff in specialties most likely to treat trauma victims is shown in Table 1. To provide an ATLS course for all 2482 Accident and Emergency Senior House Officers employed in one year would require in excess of 155 courses for these doctors alone.

ATLS providers and instructors are now available in most regions (Fig. 1) and it is obvious that local training programmes, based upon ATLS principles must be initiated. We have designed one such local course which may serve as a model for others.

\section{THE COURSE}

In Sunderland, a 6-hour course for A\&E and Orthopaedic Senior House Officers $\frac{\infty}{3}$. has been developed. Based upon ATLS principles, the course is designed to allow $\omega$ participants to fulfill those objectives necessary to the management of the seriously $\mathcal{N}^{\circ}$ injured patient on reception to the resuscitation room.

The course objectives are:

(1) Demonstration of the concepts and principles of the primary survey.

(2) Establishment of management priorities in a trauma situation.

(3) Initiation of primary management necessary within the first 15 minutes of emergency care.

(4) Demonstration of the following skills:

- Primary assessment of a moulage victim.

- Basic and advanced airway management, including endotracheal intubatiơ on adult and infant manikins, with stabilisation of the cervical spine.

- Administration of intravenous fluid therapy.

- Pleural decompression via needle thoracentesis and chest tube insertion.

- Radiographic identification of cervical spine injuries.

These objectives were selected as being those most appropriate to management during the time senior assistant is summoned.

The course is taught by local ATLS providers and instructors. Invited members of the A\&E nursing staff participate as observers. The course comprises two three hour sessions taught during the first 2 weeks of a 6-month house. The A\&E Department is staffed by General Practitioner Clinical Assistants during these sessions. The format of the sessions is outlined in Table 2.

Table 1. Junior hospital medical staff: England and Wales (30 988 ).

\begin{tabular}{lccr}
\hline & SHO & REG & SR \\
Accident \& Emergency & 1241 & 85 & 57 \\
General Surgery & 641 & 647 & 175 \\
Trauma/Orthopaedics & 680 & 401 & 142 \\
Anaesthesia & 932 & 865 & 368 \\
\hline
\end{tabular}

Source: Medical and Dental Staffing Prospects in the N.H.S. in England and Wales. Health Trends 4(21). 99-106. 1989. 


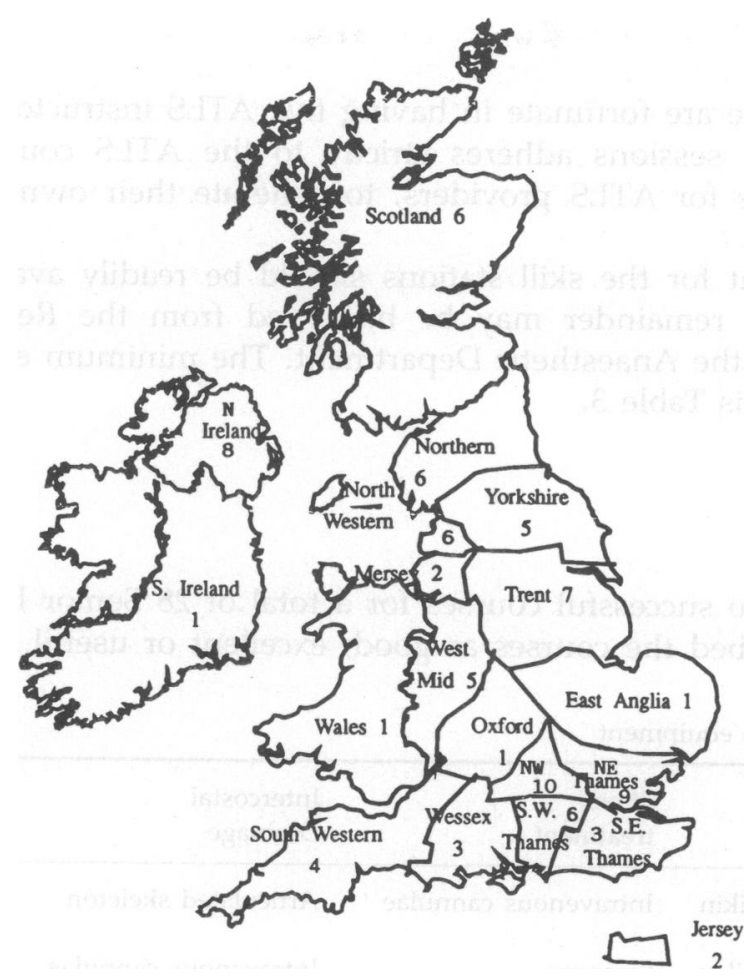

Fig. 1. Regional distribution of ATLS instructors and instructor candidates (November, 1990).

Table 2. Format of teaching sessions

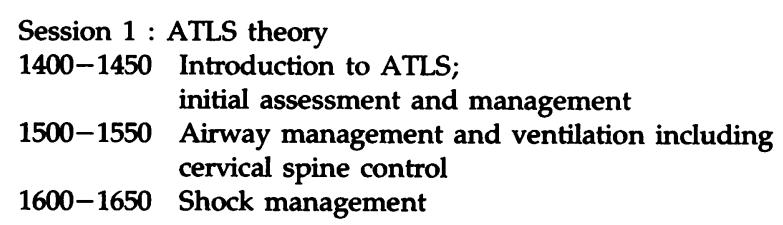

Session 2. Practical skill stations and moulage

\begin{tabular}{llccc}
\hline & $\begin{array}{l}\text { Airway } \\
\text { management }\end{array}$ & $\begin{array}{l}\text { Shock } \\
\text { treatment }\end{array}$ & $\begin{array}{l}\text { Intercostal } \\
\text { drainage }\end{array}$ & $\begin{array}{l}\text { Cervical spine } \\
\text { injuries }\end{array}$ \\
\hline $1410-1440$ & Group A & B & C & D \\
$1450-1520$ & Group D & A & B & C \\
$1530-1600$ & Group C & D & A & B \\
$1610-1640$ & Group B & C & D & A \\
$1645-1700$ & Moulage demonstration & & & \\
\hline
\end{tabular}




\section{EQUIPMENT}

In Sunderland, we are fortunate in having five ATLS instructors whose teaching $\underset{\infty}{\stackrel{8}{2}}$ of the theoretical sessions adheres strictly to the ATLS course manual. It is, $\vec{F}$ however, possible for ATLS providers, to generate their own visual aids based upon the manual.

Most equipment for the skill stations should be readily available to the A\&E Department. The remainder may be borrowed from the Regional Ambulance $\overparen{D}$ Service and from the Anaesthetic Department. The minimum equipment for each station in shown is Table 3.

\section{DISCUSSION}

We have held two successful courses for a total of 28 Senior House Officers. Of $\stackrel{\infty}{\omega}$ these, $90 \%$ described the courses as good, excellent or useful. Five doctors have $\stackrel{\text { ô }}{\text { in }}$

Table 3. Skill station equipment

\begin{tabular}{|c|c|c|c|}
\hline $\begin{array}{l}\text { Airway } \\
\text { management }\end{array}$ & $\begin{array}{l}\text { Shock } \\
\text { treatment }\end{array}$ & $\begin{array}{l}\text { Intercostal } \\
\text { Drainage }\end{array}$ & Cervical spine \\
\hline Adult intubation manikin & Intravenous cannulae & Articulated skeleton & Viewing box \\
\hline Infant intubation manikin & Syringes & Intravenous cannulae & $\begin{array}{l}\text { Cervical spine } \\
\text { Radiographs - } \\
\text { normal and abnorm? }\end{array}$ \\
\hline Oropharyngeal airways & Intravenous cannulae & Syringes & $\begin{array}{l}\text { Semirigid cervical } \\
\text { collar }\end{array}$ \\
\hline Nasopharyngeal airways & $\begin{array}{l}\text { Central venous cannu- } \\
\text { lation manikin }\end{array}$ & Intercostal drains & \\
\hline Adult endotracheal tubes & $\begin{array}{l}\text { Forearm venous cannu- } \\
\text { lation manikin }\end{array}$ & Underwater seal bottle & \\
\hline Infant endotracheal tubes & Adhesive tape & Tubing & \\
\hline $\begin{array}{l}\text { Laryngoscopes; infant and } \\
\text { adult, straight and curved }\end{array}$ & & Hand held suture & \\
\hline Magill forceps & & $\begin{array}{l}\text { Large straight artery } \\
\text { clip }\end{array}$ & \\
\hline Stethoscope & & Scalpel & \\
\hline $10 \mathrm{ml}$ syringes & & Adhesive dressings & \\
\hline \multicolumn{4}{|l|}{ Semirigid cervical collar } \\
\hline Bag valve mask device & & & \\
\hline
\end{tabular}


been offered places on ATLS provider courses. The course has been simple to organize and similar courses should be within the scope of teaching programmes in all A\&E departments. The immediate response to the seriously injured is a uniform one facilitating rapid and appropriate care in our A\&E Department.

Local courses are not an alternative to attaining Provider status on an approved ATLS course, but provide an interim means of ensuring that junior staff likely to encounter severely injured patients are competent to manage them during the first 15 minutes. Those not pursuing surgical careers have enjoyed the benefit of having at their fingertips a working knowledge of a proven system of assessment and resuscitation. General Practitioner trainees who subsequently join Immediate Care schemes should therefore disseminate ATLS principles into the field of prehospital care.

Improved communication between junior and senior staff involved in trauma management has been facilitated, to the benefit of the patient. Our course should ideally be extended to incorporate junior staff from the specialties of General Surgery and Anaesthetics, in line with the Royal College of Surgeons recommendations that all those involved in care of the seriously injured be ATLS trained (Royal College of Surgeons, 1988).

\section{ACKNOWLEDGEMENTS}

We are grateful to Janet Corbett and Claire Barnes for secretarial help, Northumbria Ambulance Service for the loan of equipment, Mrs E. Henry for her organizational assistance, and Angela Ezekiel for providing the information for Figure 1.

\section{REFERENCES}

Advanced Trauma Life Support Programme (1988) Instructor Manual. Committee on Trauma, American College of Surgeons.

Royal College of Surgeons of England (1988) Report of the Working Party on the Management of Patients with Major Injuries. 